\title{
Influence of Microtopography and Soil Treatments on Tree Establishment on a Reclaimed Quarry
}

\author{
Jennifer Franklin * ${ }^{-1}$ and David Buckley \\ Department of Forestry, Wildlife and Fisheries, University of Tennessee, Knoxville, TN 37996, USA \\ * Correspondence: jafranklin@utk.edu; Tel.: +1-(865)-974-2724
}

Received: 10 June 2019; Accepted: 11 July 2019; Published: 18 July 2019

check for updates

\begin{abstract}
Research Highlights: Reclaimed minesites provide an opportunity to establish plantings of tree species of special concern, such as the American chestnut (Castanea dentata (Marshall) Borkh.), white oak (Quercus alba L.) and shortleaf pine (Pinus echinata Mill.). Background and Objectives: Reforestation success may be influenced by the physical and chemical characteristics of the substrate, which can be manipulated as part of the reclamation process. The objective of this study was to test the effects of three common reclamation treatments on the establishment of the above species on quarry overburden. Materials and Methods: This study tested the influence of lime and fertilizer (100 or $400 \mathrm{~kg} / \mathrm{ha} \mathrm{N}$ ) application, loose dumped substrate vs. single pass grading and the resulting microtopography, on the survival and growth of planted 1:0 seedlings over seven years on reclaimed quarry overburden. Results: Grading had a negative impact on the survival of all species. Lime and fertilizer also influenced survival, but effects differed between species. A single application of fertilizer at the time of planting had a lasting and significant influence on the growth of all species. At year seven, across all species, microtopography influenced root collar diameter. The greatest growth was seen on the east upper, and west mid-slope positions. Conclusions: Fertilization and microtopography created by different site preparation techniques at the time of stand establishment can have a significant influence on tree growth over the first seven years.
\end{abstract}

Keywords: mine reclamation; forest restoration; silviculture

\section{Introduction}

There is substantial interest on the part of managers and landowners in restoring American chestnut (Castanea dentata (Marshall) Borkh.), white oak (Quercus alba L.) and shortleaf pine (Pinus echinata Mill.) in multiple regions of the eastern U.S. American chestnut has been classified as a foundation species due to its important roles in ecosystem processes and supporting a wide variety of seed predators and ecosystem processes, and has been all but eliminated by the chestnut blight (Cryphonectria parasitica (Murrill) Barr) throughout its former range [1-4]. White oak is also important in supporting wildlife and serves as a source of valuable forest products, but is currently not regenerating in sufficient numbers due to altered fire regimes, increased competition with fire-sensitive hardwoods, and deer browsing [5]. Different successional stages in shortleaf pine-dominated ecosystems provide key structural attributes for bobwhite quail and a wide range of other bird and mammal species [6-8]. Shortleaf pine ecosystems have declined due to altered fire regimes and a greater focus on loblolly pine (Pinus taeda L.) management $[9,10]$.

Artificial regeneration is a particularly important tool for restoration of native species and forest ecosystems when local sources of natural regeneration no longer exist. Artificial regeneration involving the planting of nursery seedlings can bypass many problems that are important early in the regeneration process, such as a lack of suitable seedbeds, poor germination conditions, and seed predation. The success of artificial regeneration of nursery stock can be undermined, however, by 
heavy competition with more aggressive native and exotic plant species. Reclaimed coal mines, rock quarries, and other areas impacted by the complete removal of vegetation and upper soil horizons provide opportunities to restore native species and forest ecosystems without the negative effects of well-established competitors on planted nursery seedlings.

Due to the extent of surface mining for coal in several states in the eastern U.S., more research has been conducted on the restoration of native species on reclaimed coal mine overburden materials than on quarry overburden materials. Although rock quarries occupy a smaller percentage of the landscape than coal mines, active movement and placement of quarry overburden materials often continues over many decades, and quarries are often located in close proximity to population centers where they are both highly visible and have the potential to provide a number of valuable ecosystem services following restoration. Quarry overburden materials are similar to coal mine overburden materials in that they contain no organic matter, roots, or seeds. Their physical and chemical properties are likely to differ, however, due to differences in the geology underlying coal mines and rock quarries.

Several decades of coal mine reforestation research have established that many native species, including the ecologically and economically important oaks and pines, can be restored on mine overburden materials [11]. Another important finding of coal mine research is that excessive compaction after overburden placement is extremely detrimental to the growth and long-term survival of planted trees. Compaction of the deeper layers of reconstructed landforms is important for improving their overall stability, but the most recent recommendations call for minimizing compaction in the top $1.22 \mathrm{~m}$ of overburden material. This practice improves the percolation of rainfall, reduces runoff, enhances aeration, and ensures adequate rooting space for planted trees [12]. It is likely that the finding that compaction should be minimized near the surface during mine reclamation is equally applicable to quarry overburden materials.

Methods of dumping and grading overburden materials during their final placement have an important influence on compaction, and also the characteristics of tree planting sites including soil moisture, light, and temperature regimes. In general, the fewer the grading passes, the better, and the more heterogeneous the microtopography, the more niches available for plants and animals. In addition to the physical effects of different overburden placement techniques, it is also possible to correct chemical problems such as nutrient deficiencies and extremely acid or basic soil pH. Much less information is available on the amendment of $\mathrm{pH}$ and nutrient levels in quarry overburden than in coal mine overburden, and effects of different quarry overburden placement methods on compaction and microsite heterogeneity are poorly documented. In order to fill these knowledge gaps, we implemented a field study in 2009 to address two research questions: (1) what are the effects of the microtopography created by different quarry overburden placement methods, and (2) how will fertilizer application rate, liming alone, and a combination of the two amendments affect the establishment, growth, and survival of planted American chestnut, white oak, and shortleaf pine seedlings?

\section{Materials and Methods}

\subsection{Overburden Placement}

The study area is a 5 ha experimental valley fill on the University of Tennessee Forest Resources Research and Education Center (FRREC), which adjoins a Rogers Group rock quarry in Oak Ridge, TN. Overburden materials generated by the current operations were transported from the quarry site to the study area in 2009 and placed in a manner that was consistent with the Forestry Reclamation Approach (FRA) [13]. Once a base was established and compacted, fresh overburden material was placed over the compacted material in loosely dumped piles arranged in rows (Figure 1). The piles were approximately $2 \mathrm{~m}$ in height when initially placed to ensure there would be at least $1.22 \mathrm{~m}$ of uncompacted material at the surface after settling, as recommended under the FRA. The rows of piles were arranged on the site (Figure 1) so that drainage flowed from the depressions between rows 
downhill to an off-site sediment pond. This ensured that fertilizer and lime would not move between treated rows and controls.

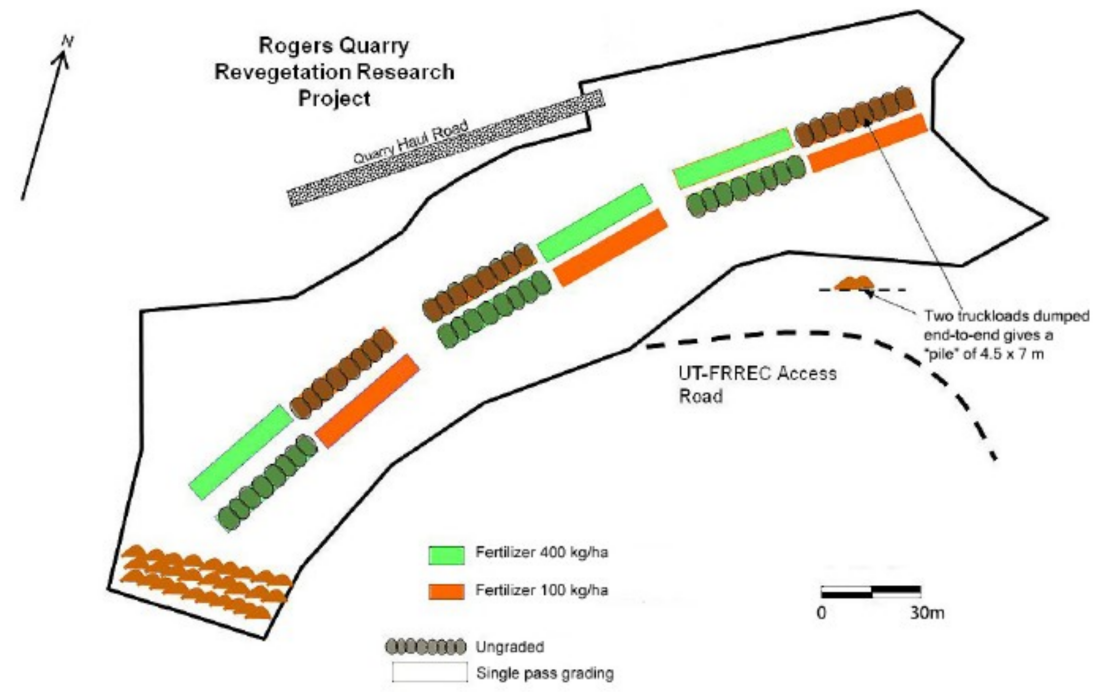

Figure 1. Arrangement of plots and treatments on a reclaimed quarry site in Oak Ridge, TN. Ungraded plots appear darker in color.

\subsection{Experimental Design}

A series of 12 rows, hereafter called "plots", were created on the site (Figure 1). Six of the 12 plots remained ungraded after dumping without any further working. The lightest tracked vehicle available was used to level the tops of piles in the remaining 6 plots with a single pass to create a minimally compacted, level surface [12]. Plots at one end of the site varied from those at the other in terms of proximity to the adjacent forest and some substrate properties. Therefore, the plots were blocked into three replicates of four plots each, which created a randomized complete block design.

Lime (Liquid lime Plus, Caudill Seed Co., Louisville, KY, USA) was applied as a suspension to one randomly selected half of each plot. Liquid lime $\left(\mathrm{CaCO}_{3}\right)$ application rate $(456.78 \mathrm{~L} / \mathrm{Ha})$ was based on initial soil analyses and typical application rates recommended for the region. The first liquid lime application occurred on 2 June, 2009, and a second application was carried out on 26 May, 2010, due to an April, 2010 substrate test that indicated the $\mathrm{pH}$ in treated plots had returned to levels observed in the unlimed plots.

Water-soluble fertilizer (20:20:20 N:P:K) was applied to provide nitrogen at the rate of $100 \mathrm{~kg} / \mathrm{ha}$ to one randomly selected graded and one randomly selected ungraded plot within each block (Figure 1), 2 weeks prior to planting in May, 2009. Likewise, the same fertilizer was applied to provide nitrogen at the rate of $400 \mathrm{~kg} /$ ha to one randomly selected graded and one randomly selected ungraded plot within each block (Figure 1). This assignment of treatments resulted in 3 replicates of each of 4 amendment treatments: no lime + low $\mathrm{N}$, no lime + high $\mathrm{N}$, lime + low $\mathrm{N}$, and lime + high $\mathrm{N}$. The two levels of each grading, lime, and fertilization treatment represent different conditions that could be imposed during the reclamation process. Thus, there is no true control treatment, but graded, with lime and high $\mathrm{N}$ is the condition most often created on recently reclaimed minesites.

All stems planted were one-year-old, bare-root nursery seedlings. A total of three species were planted: white oak, shortleaf pine, and American chestnut. The TN State Tree nursery produced the white oak and shortleaf pine seedlings and the American chestnut seedlings were first and second generation back-crossed American $\times$ Chinese hybrids (genetically 3/4 to 7/8 American) produced as part of the breeding program of the American Chestnut Foundation, and provided by the U.S. Forest Service. Monocultural blocks containing 16 seedlings of each species were planted in all combinations of grading, fertilization, and liming treatments. Seedlings were planted in a $1 \times 1.5 \mathrm{~m}$ grid pattern on ungraded plots. Monocultural blocks on ungraded plots were planted so that 4 seedlings were located 
on the slopes of each pile facing each cardinal direction. On each aspect, seedlings were planted in a square $1 \times 1 \mathrm{~m}$ apart, with two seedlings planted in high, and two in mid-slope positions. Each group of four was placed such that seedlings at the top of the slope were approximately $1 \mathrm{~m}$ from those in the adjacent square, while those at mid-slope were 1.5 to $2 \mathrm{~m}$ apart. No ground covers were planted, and any native and exotic herb, shrub, and tree species that colonized plots from surrounding seed sources were allowed to persist.

\subsection{Data Collection and Analysis}

Soil was collected from each plot in March 2009 prior to the application of amendments. Overall texture of the substrate was classified as a sandy loam with $66.2 \%$ rocks ( $>2 \mathrm{~mm}$ diameter) and $33.8 \%$ fines determined from a composite sample comprised of sub-samples from all the plots as previously described [14]. Soil samples were collected along with soil moisture and temperature measurements in July and December of 2009, in April, June and July of 2010, and in July and August of 2011. The pH analysis was performed in triplicate for each sample, which was a composite of subsamples collected within each half plot. Percent volumetric soil moisture was measured with a Trase time domain reflectometry probe (Soilmoisture Equipment Corp., Santa Barbara, CA, USA). Soil temperature was measured with a $15.24 \mathrm{~cm}$ Reotemp heavy duty soil thermometer (Reotemp Instruments, San Diego, CA, USA). Measurements of both soil moisture and soil temperature were taken in the four corners and center of each graded sub-plot, and in each cardinal direction at the mid-sloped position as well as on the top of mounds of ungraded sub-plots.

Seedling growth and survival was monitored through measurements of height and root collar diameter (RCD). Seedlings were measured just after planting, and again in December of 2009, June of 2010, July of 2011 and 2014, and September of 2016.

Treatment effects over time were investigated using a multivariate general linear model (GLM) with repeated measures (SPSS 25.0, SPSS Inc., Chicago, IL, USA) for each species. Between-subjects effects were considered significant where the time $\times$ main effect interaction was significant at $p<0.05$. Any outliers identified were not included in the models. A GLM was employed to test for the effects of slope position and aspect on tree height and RCD at year 7, using all species in the analysis as there was no significant difference between species in their response. A GLM was used to test for differences in soil moisture and temperature, using time as a co-variate to account for diurnal fluctuations. A Duncan post-hoc analysis test was used when significant effects were found.

\section{Results}

Mean volumetric soil moisture was significantly greater $(16.06 \% \pm 0.37 \mathrm{SE})$ in graded plots than in ungraded plots with mounds $(15.25 \pm 0.41 \mathrm{SE})$, while soil temperature did not differ between grading treatments. Survival of planted white oak was greater in ungraded than graded plots, but the effects on chestnut and pine were not significant (Figure 2a). Grading had no significant influence on the height or root collar diameter growth of any species. 

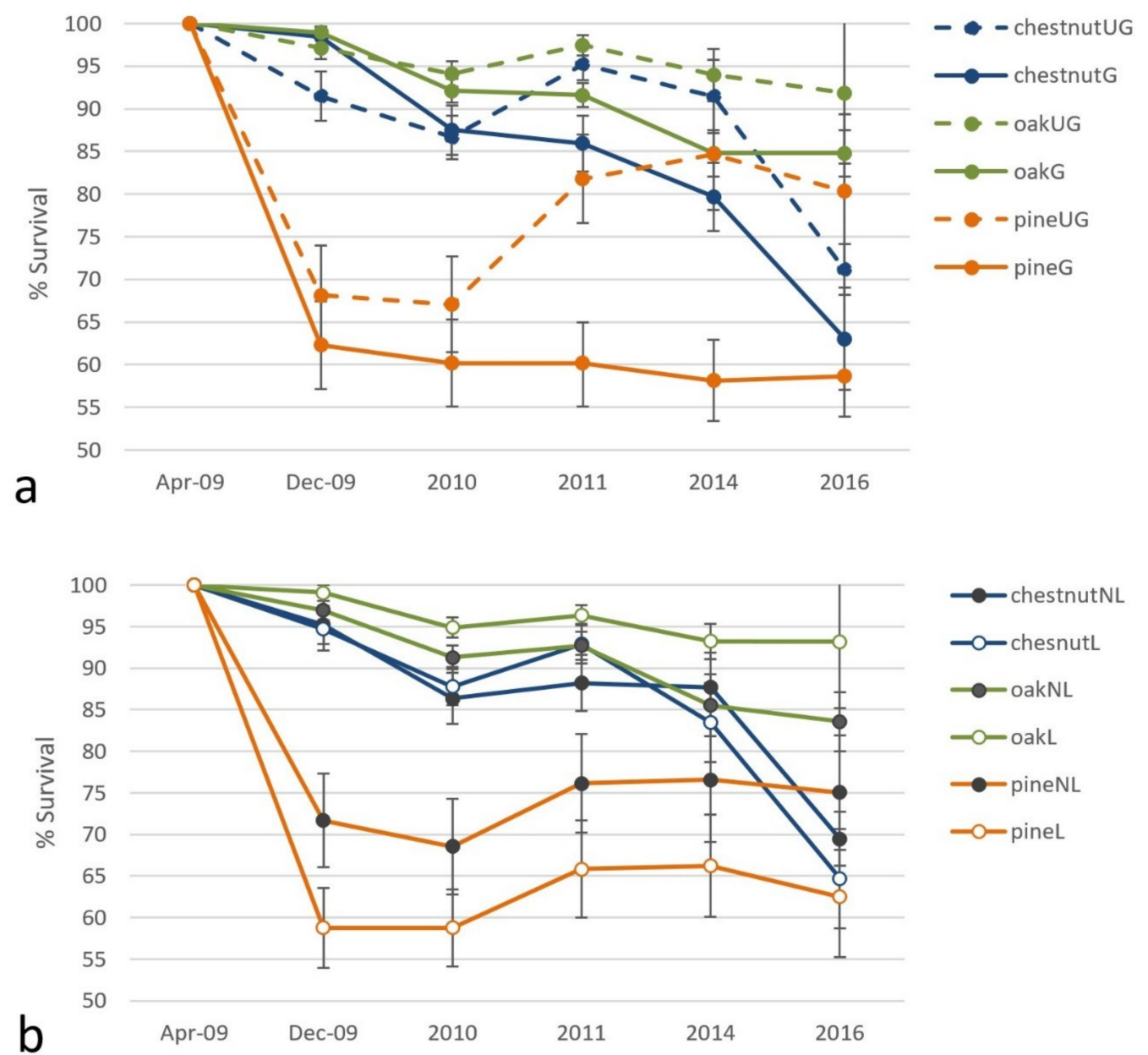

Figure 2. (a) Survival, by grading treatment, of shortleaf pine (orange), white oak (green) and American chestnut (blue), across years; solid lines indicate graded (G) and dashed line un-graded (UG) treatments, (b) Survival, by lime treatment, of shortleaf pine (orange), white oak (green) and American chestnut (blue), across years; white circles indicate lime (L) and black circles no lime (NL) treatments. Bars indicate standard error.

The liming treatment increased soil $\mathrm{pH}$ from an average of 4.7 to 4.9 in 2009, and from 4.9 to 5.1 in 2010. Soil pH values of lime treatments, however, returned to pre-treatment values within a year of each application. The application of lime decreased the survival of pine, but increased the survival of oak (Figure 2b). The lime treatment had no influence on chestnut survival.

Survival of pine was significantly lower in the $400 \mathrm{~kg} / \mathrm{ha}$ fertilization treatment, while survival of oak and chestnut were not significantly different between fertilization treatments (Figure 3a). Both mean height and mean root collar diameter of each species was significantly greater with a higher rate of fertilization (Figure 3b,c). 

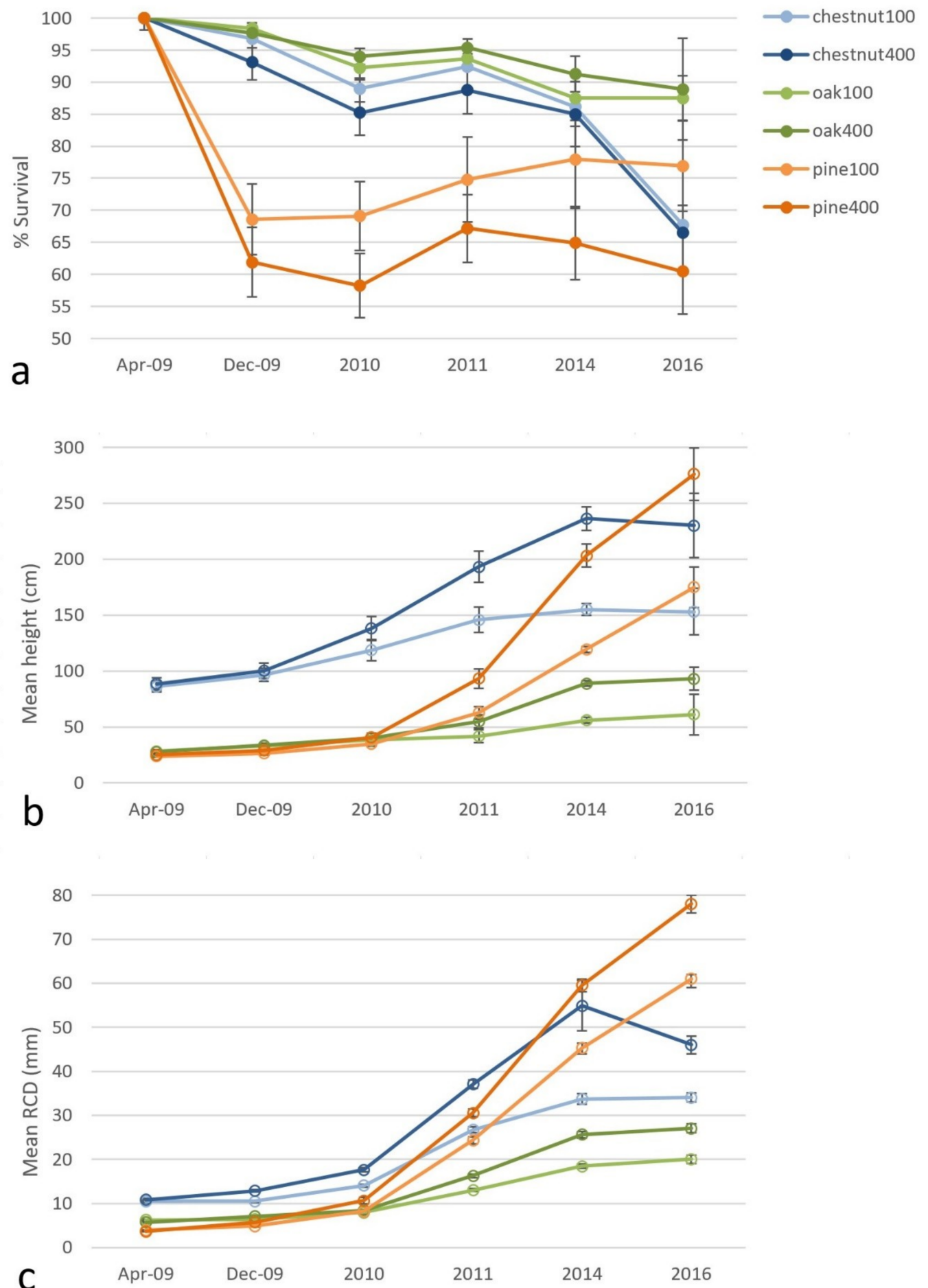

Figure 3. Shortleaf pine (orange), white oak (green) and American chestnut (blue) responses to fertilization at the rate of $400 \mathrm{kgN} / \mathrm{ha}$ or $100 \mathrm{kgN} / \mathrm{ha}$. (a) survival; (b) mean height; (c) mean root collar diameter. Bars indicate standard error.

Investigation of seedling performance in relation to location on the mounds comprising the ungraded plots revealed differences in the root collar diameter growth of all species combined across slope positions and aspects. Mean root collar diameter growth of all species combined was significantly greater at mid-slope positions with a western aspect than all other slope position and aspect combinations in 2016 (Figure 4). In addition, mean root collar diameter growth of all species 
combined was significantly less at mid-slope positions with an eastern aspect than at upper slope positions with an eastern aspect and mid-slope positions with a western aspect (Figure 5).

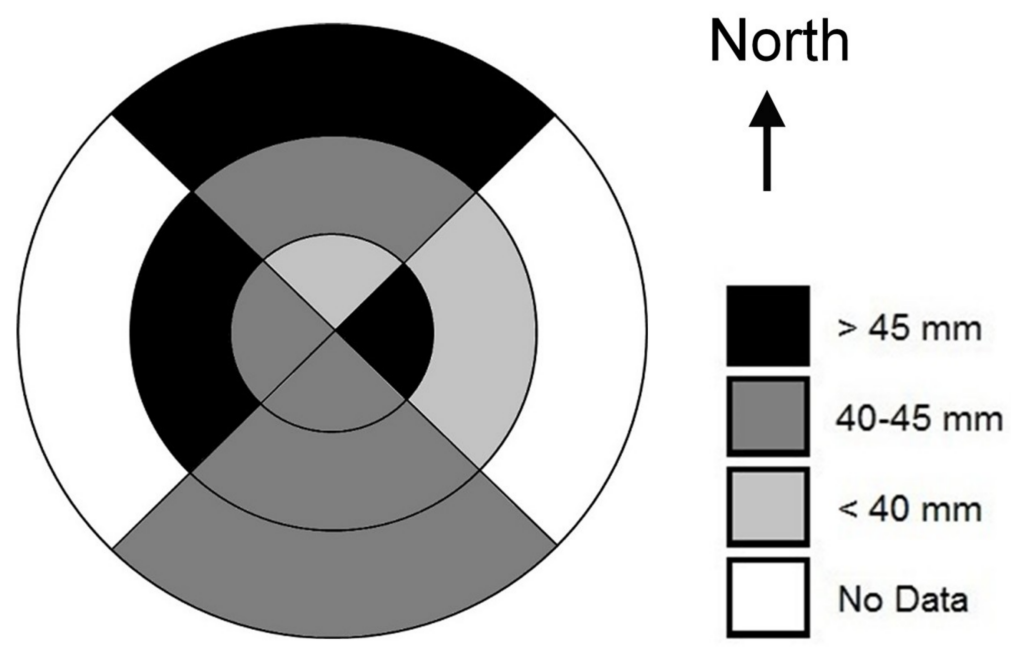

Figure 4. Mean 2016 root collar diameter of seedlings planted in ungraded plots, by slope position and aspect. The center of the diagram corresponds to the top of a mound.
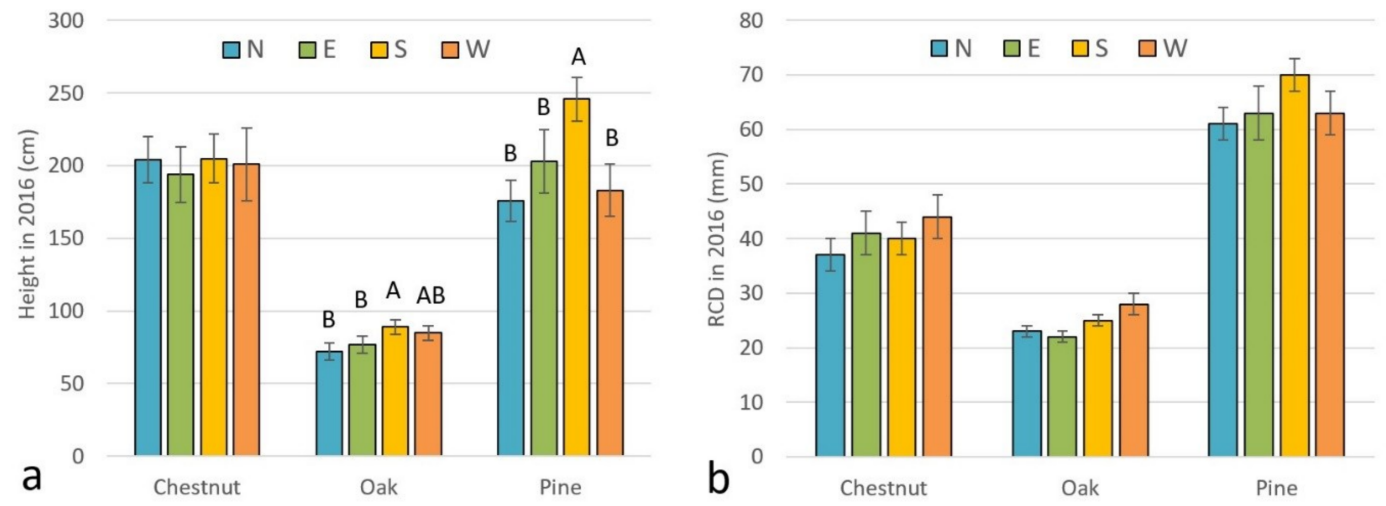

Figure 5. Mean (a) height and (b) root collar diameter of seedlings planted on ungraded plots, on slopes facing each of the four cardinal directions. Different letters indicate significant differences between aspects for that particular species. An absence of letters indicates that no significant difference was found.

In relation to aspect alone, 2016 height growth of white oak was significantly greater on southern aspects than northern and western aspects (Figure 5a), and growth of shortleaf pine was significantly greater on southern aspects than all otheraspects (Figure 5a). There were no significant differences in root collar diameter growth among aspects in 2016 (Figure 5b). Mean soil temperatures were significantly lower on northern aspects than on all other aspects, and significantly higher on the tops of mounds than on northern, western, eastern, and southern aspects (Figure 6). Mean percent volumetric soil moisture was variable across and within sampling dates (Figure 7), and no significant differences in mean percent volumetric soil moisture were detected among aspects. 


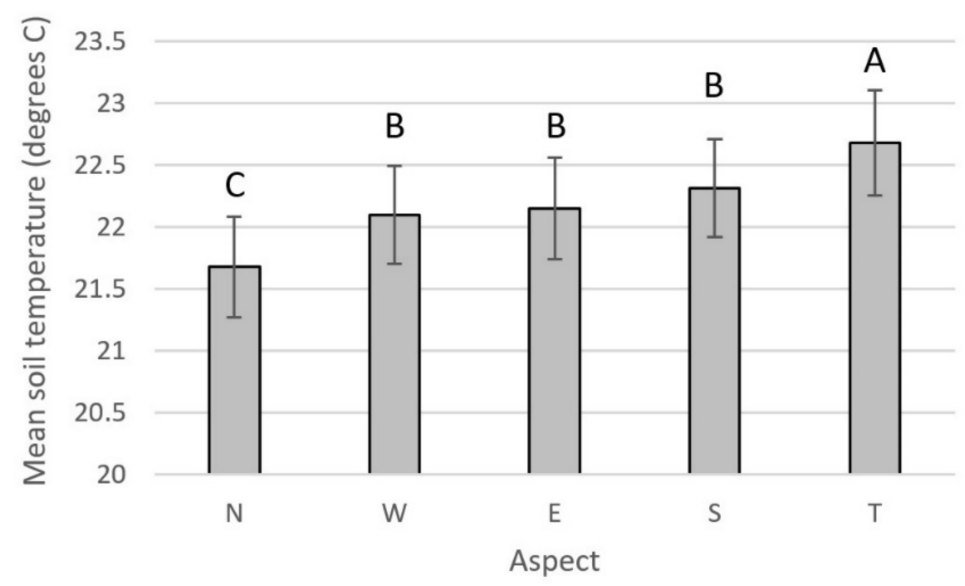

Figure 6. Mean soil temperature, across all measurement dates, on each aspect and the tops (T) of mounds. Bars indicate standard error. Different letters indicate a significant difference between treatments at $p<0.05$, with date and time of day included in the model.

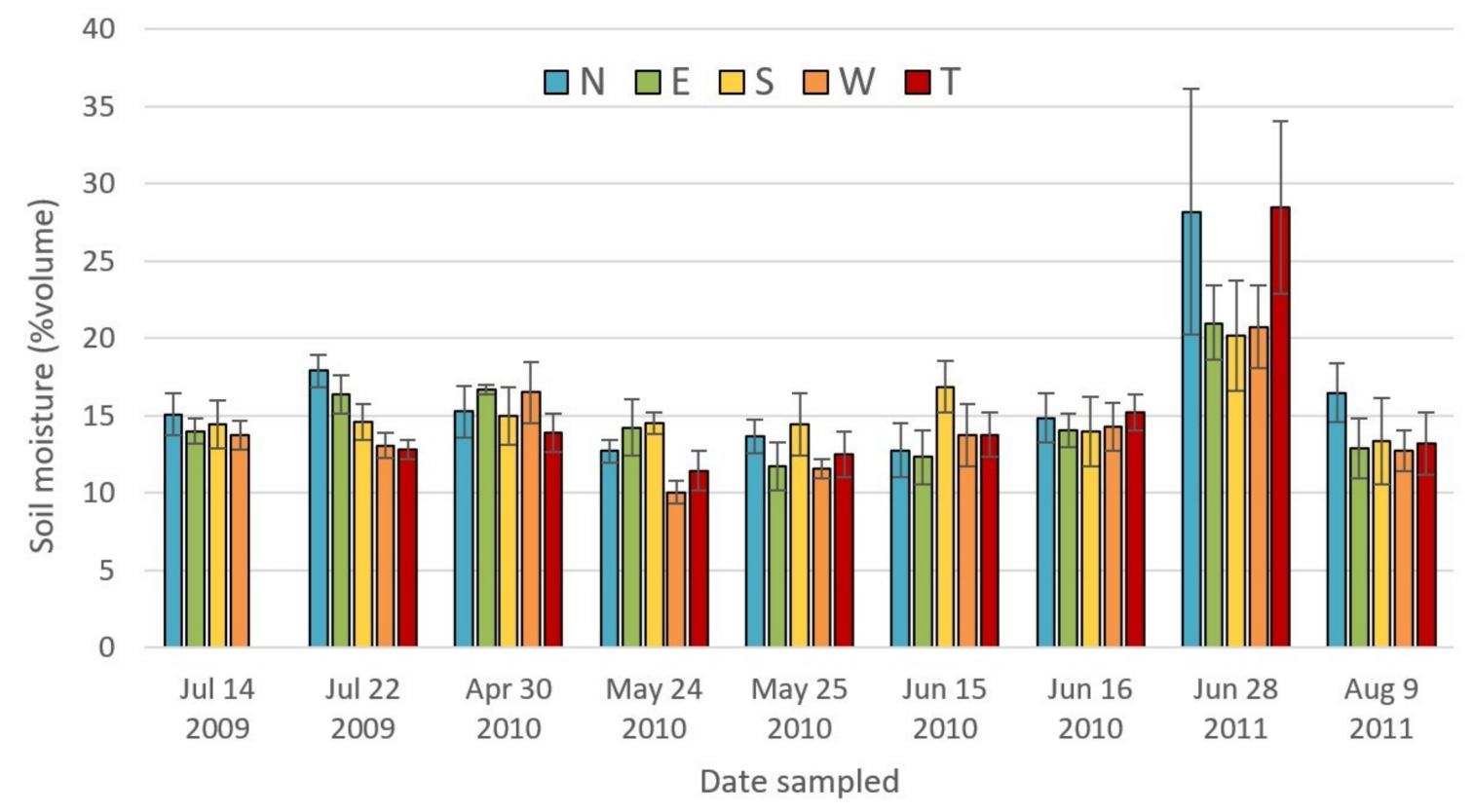

Figure 7. Mean volumetric soil moisture on each aspect and the tops (T) of mounds on each sampling date.

No differences in mean height were found across slope positions for any species (Figure 8a). Mean root collar diameter of pines were significantly lower at upper slope positions than at mid and lower slope positions (Figure $8 \mathrm{~b}$ ). Mean root collar diameters of other species did not differ among slope positions. 

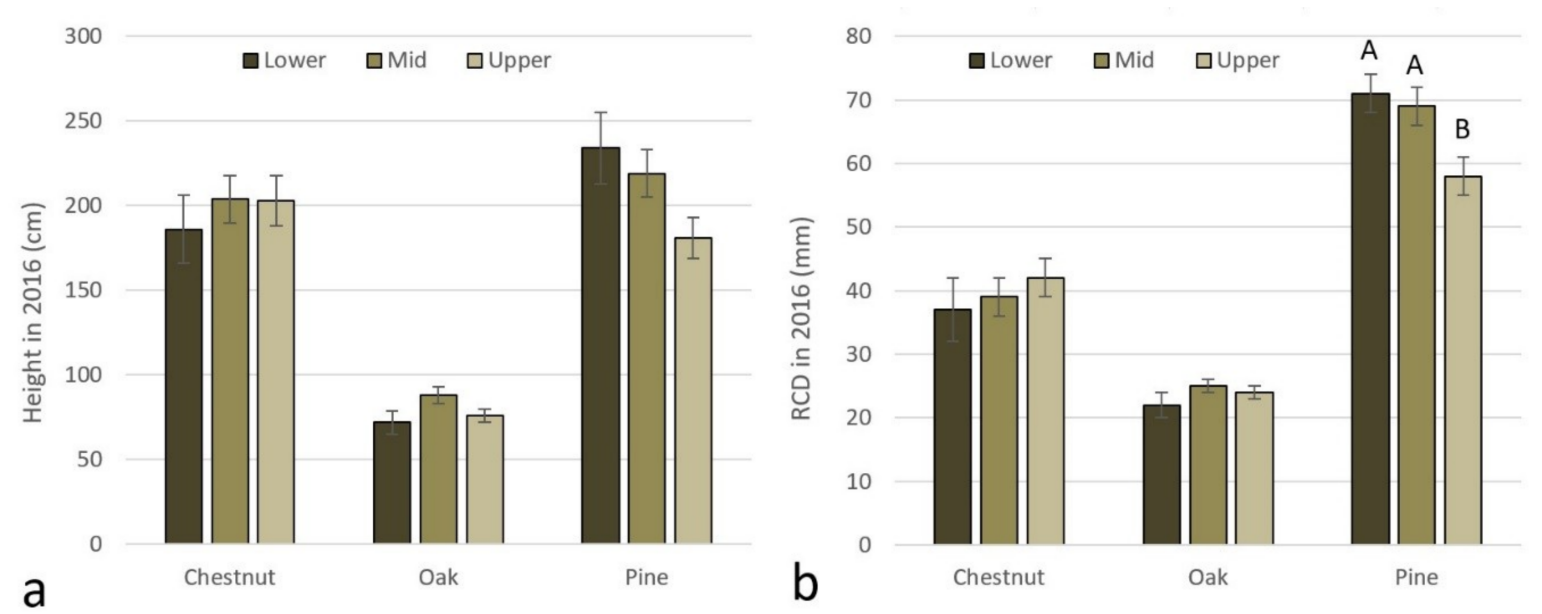

Figure 8. Mean 2016 (a) height and (b) root collar diameter of seedlings at lower, mid, and upper slope positions. Different letters indicate significant differences between slope positions within a species. An absence of letters indicates that no significant difference was found.

\section{Discussion}

Lower elevation of the soil surface and a lesser amount of surface area exposed to the sun and wind likely contributed to the greater mean volumetric soil moisture measured in graded plots. The greater survival of oak on ungraded plots may be due to lower compaction. Although the effect of grading was not significant in this study, shortleaf pine seedlings have been found to be sensitive to soil compaction over the short term [15]. An increase in survival was observed between 2010 and 2011, particularly in the ungraded plots. For oak and chestnut, this may be attributed to individuals re-sprouting from the root collar. In some cases, seedlings were likely buried by shifting substrate, and/or had lost shoots to herbivory as there is a high deer presence in the area, and not observed in 2010. All three species are known to be prolific in sprout production. The larger increase in survival seen for pine over this period cannot be explained entirely by re-sprouting, but volunteer seedlings including several pine species had appeared on the plots in 2010, and by 2011 some volunteer shortleaf had reached a size similar to that of the planted trees, thus would have been included during tree measurements.

Although lime application resulted in only a temporary 0.2 increase in $\mathrm{pH}$, this affected both pine and white oak. Shortleaf pine is reported to occur primarily in soils of 4.5 to $7 \mathrm{pH}$, and is more commonly found towards the lower end of this range [16]. However, one study found that this species is highly sensitive to the presence of soluble calcium, more so than $\mathrm{pH}$, with seedling death occurring at moderately high calcium levels even in acidic soils [17]. It is likely that liming had no effect on the survival and growth of planted American chestnut seedlings due to the innate tolerance of American chestnut and its adaptability to a wide range of soil types.

Due to uptake, leaching, and other ecosystem processes, it can be argued that the effects of a one-time fertilizer application may diminish over time. The persistent pattern of greater height and root collar diameter growth in the fertilized plots may have been perpetuated by the more competitive canopy position, leaf area, and photosynthetic capacity of saplings that gained an advantage from the fertilizer treatment early on. The strong effect of fertilization was likely due to the very low initial soil nitrogen levels which would have been an important growth limiting factor for all species on this site.

Results for the root collar diameter growth of all species combined across different topographical positions in ungraded plots were both consistent and inconsistent with the results of previous studies investigating the effect of slope position, aspect, and landform shape on microclimate and tree growth [18-21]. The significantly greater root collar diameter growth observed in mid-slope positions with a western aspect than in the upper-slope positions with a western aspect may have been the result of less incoming direct beam radiation, lower temperatures, greater soil moisture, and greater nutrient supply on lower slope positions than on upper slope positions $[18,20]$. In contrast, the significantly 
greater root collar diameter growth observed at mid-slope positions with western aspects than in all other combinations of slope position and aspect, including lower slopes with a northern aspect (which should have been even cooler and moister [18,19]), is more difficult to explain. Further, the pattern observed among slope positions on the western aspect was reversed on the eastern aspect, where root collar diameter growth was significantly lower at the mid-slope position than at the upper slope position.

The significantly greater height growth of white oak and shortleaf pine observed on southern aspects than northern aspects is inconsistent with the potential for greater growth due to less incoming radiation, cooler temperatures, and greater moisture and nutrient supply on northern aspects [18,19]. The significantly lower soil temperatures measured on the northern aspects of mounds on the study sites suggest that the evaporation of soil moisture should have been reduced on northern aspects, leading to increased availability of soil moisture and nutrient uptake. Actual soil moisture levels measured on the study sites, however, did not differ significantly among aspects on any of the sampling dates. The significantly lower root collar diameter growth in shortleaf pine observed on upper slope positions is consistent with greater drainage of soil moisture from the tops of mounds. Although shortleaf pine can grow on shallow, rocky soils, it has been described as sensitive to soils with excessive internal drainage [22].

Results generated by previous studies suggest that the impact of slope position, aspect, and other terrain variables on tree growth varies widely with tree species, study sites, and measurement protocols [20]. Although some of the relationships observed in this study between height growth, diameter growth, and different topographical positions are difficult to interpret, the statistically significant differences in tree growth observed suggest that further studies involving different microtopographical features and optimum matches between slope positions, aspects, and species on reclaimed quarries are warranted. Pit and mound topography created through the windthrow of canopy trees adds structural heterogeneity and habitat diversity in native forest ecosystems, and the construction of undulating terrain and pits and mounds has been recognized as a potentially important practice in mine reclamation and reforestation [23-25]. Shortleaf pine had a high first-year mortality, suggesting that it is much more susceptible to planting stress than either of the hardwoods. Survival was negatively influenced by lime application, while growth was greatest at the higher fertilization rate and on the southern aspect of ungraded plots. White oak had high early survival rates, particularly on limed and ungraded plots, showing its preference for loose, less acidic soils. This slower growing species showed a less pronounced growth response to fertilization than did the other species. American chestnut was the least sensitive of the tested species, responding to fertilization but not to lime or microtopography.

The strong and significant growth response to a single application of fertilizer at the time of planting may have been due to the very low initial fertility of the overburden material, and may differ from effects on more fertile sites, or sites with greater herbaceous competition. The microtopography created by loose placement of the material influenced soil temperature, and contributed to variation in tree growth rates. Growth on the southern aspect was less variable, while on other aspects, growth of trees was sensitive to the position on the slope. This study found effects of amendments and microtopography on stand establishment over seven years, but whether these continue to influence trees over the longer term is unknown.

\section{Conclusions}

Shortleaf pine had a high first-year mortality, suggesting that it is much more susceptible to planting stress than either of the hardwoods. Survival was negatively influenced by lime application, while growth was greatest at the higher fertilization rate and on the southern aspect of ungraded plots. White oak had high early survival rates, particularly on limed and ungraded plots, showing its preference for loose, less acidic soils. This slower growing species showed a less pronounced growth 
response to fertilization than did the other species. American chestnut was the least sensitive of the tested species, responding to fertilization but not to lime or microtopography.

The strong and significant growth response to a single application of fertilizer at the time of planting may have been due to the very low initial fertility of the overburden material, and may differ from effects on more fertile sites, or sites with greater herbaceous competition. The microtopography created by loose placement of the material influenced soil temperature, and contributed to variation in tree growth rates. Growth on the southern aspect was less variable, while on other aspects, growth of trees was sensitive to the position on the slope. This study found effects of amendments and microtopography on stand establishment over seven years, but whether these continue to influence trees over the longer term is unknown.

Author Contributions: Both J.F. and D.B. contributed equally to development of the project, to experimental design, to interpretation of the data, and to manuscript preparation. Data collection and analysis was primarily the responsibility of Jennifer Franklin.

Funding: This research was funded by Rogers Group Inc., Oak Ridge TN, the University of Tennessee Institute of Agriculture, and the USDA National Institute of Food and Agriculture (Project No. TEN00MS-110 and TEN00MS-111, Accession No. 1014114).

Acknowledgments: We would like to thank the University of Tennessee Forest Resources Research and Education Center for facilitating this project, and Veronica DeLima Niebles for technical assistance.

Conflicts of Interest: The authors declare no conflict of interest.

\section{References}

1. Ellison, A.M.; Bank, M.S.; Clinton, B.D.; Colburn, E.A.; Elliott, K.; Ford, C.R.; Foster, D.R.; Kloeppel, B.D.; Knoepp, J.D.; Lovett, G.M. Loss of foundation species: Consequences for the structure and dynamics of forested ecosystems. Front. Ecol. Environ. 2005, 3, 479-486. [CrossRef]

2. Dalgleish, H.J.; Swihart, R.K. American chestnut past and future: Implications of restoration for resource pulses and consumer populations of eastern US forests. Restor. Ecol. 2012, 20, 490-497. [CrossRef]

3. Dalgleish, H.; Nelson, C.; Scrivani, J.; Jacobs, D. Consequences of shifts in abundance and distribution of American chestnut for restoration of a foundation forest tree. Forests 2015, 7, 4. [CrossRef]

4. Powell, W. The American chestnut's genetic rebirth. Sci. Am. 2014, 310, 68-73. [CrossRef] [PubMed]

5. Lorimer, C.G. Causes of the oak regeneration problem. In Proceedings of the Oak regeneration: Serious Problems; Practical Recommendations: Knoxville, TN, USA, 1992; pp. 14-39.

6. Guldin, J.M. Restoration and management of shortleaf pine in pure and mixed stands-science, empirical observation, and the wishful application of generalities. In Proceedings of Shortleaf pine restoration and ecology in the Ozarks: proceedings of a symposium, Springfield, MO, USA, 7-9 November 2006; Kabrick, J.M., Dey, D.C., David, G., Eds.; US Department of Agriculture, Forest Service, Northern Research Station: Newtown Square, PA, USA, 2006; pp. 47-58.

7. Masters, R.E. The importance of shortleaf pine for wildlife and diversity in mixed oak-pine forests and in pine-grassland woodlands. In Shortleaf Pine Restoration and Ecology in the Ozarks, Proceedings of A Symposium, Springfield, MO, USA, 7-9 November 2006; Kabrick, J.M., Dey, D.C., David, G., Eds.; General Technical Report NRS-P-15; US Department of Agriculture, Forest Service, Northern Research Station: Newtown Square, PA, USA, 2006; pp. 35-46.

8. Black, M. Managing shortleaf pine for bobwhite quail. In Proceedings of the Shortleaf Pine Conference: East Meets West, Huntsville, AL, USA, 20-22 September 2011; pp. 37-38.

9. Al-Sherif, E.; Hegazy, A.; Gomaa, N.; Hassan, M. Allelopathic effect of black mustard tissues and root exudates on some crops and weeds. Planta Daninha 2013, 31, 11-19. [CrossRef]

10. Oswalt, C.M. Spatial and Temporal Trends of the Shortleaf Pine Resource in the Eastern United States. Available online: http://www.forestry.ok.gov/Websites/forestry/images/Proceedings_of_Shorlteaf_Pine_ Conference_East_meets_West.pdf\#page=39 (accessed on 15 July 2019).

11. Torbert, J.L.; Burger, J. Forest land reclamation. In Reclamation of Drastically Disturbed Lands; Barnhisel, R.I., Darmody, R.G., Daniels, W.L., Eds.; American Agronomy Society: Madison, WI, USA, 2000; pp. 371-398. 
12. Sweigard, R.; Burger, J.; Zipper, C.; Skousen, J.; Barton, C.; Angel, P. Low Compaction Grading to Enforce Reforestation Success on Coal Surface Mines; Office of Surface Mining, Forest Reclamation Advisory No. 3.; US Department of Agriculture, Forest Service, Northern Research Station: Newtown Square, PA, USA, 2007.

13. Burger, J.A.; Graves, D.; Angel, P.N.; Davis, V.M.; Zipper, C.E. The Forestry Reclamation Approach, Appalachian Regional Reforestation Initiative; Forest Reclamation Advisory Number 2; U.S. Department of the Interior: Washington, DC, USA, 2005.

14. deLima, V.; Franklin, J.A.; Buckley, D.S. Tree response to substrate and grading treatments on quarry overburden. In Proceedings of the National Meeting of the American Society of Mining and Reclamation; Sciences Leading to Success: Bismarck, ND, USA, 2011; pp. 166-180.

15. Gwaze, D.; Johanson, M.; Hauser, C. Long-term soil and shortleaf pine responses to site preparation ripping. New For. 2007, 34, 143-152. [CrossRef]

16. Prasad, A.; Iverson, L.; Matthews, S.; Peters, M. 2007-Ongoing. A Climate Change Atlas for 134 Forest Tree Species of the Eastern United States [database]. Retrieved from US Department of Agriculture, Forest Service Website. Northern Research Station USDA Forest Service: Delaware, OH, USA. Available online: http://www.nrs.fs.fed.us/atlas/tree (accessed on 31 May 2019).

17. Chapman, A. Tolerance of shortleaf pine seedlings for some variations in soluble calcium and $\mathrm{H}$-ion concentration. Plant Physiol. 1941, 16, 313. [CrossRef] [PubMed]

18. Geiger, R.; Aron, R.H.; Todhunter, P. The Climate Near the Ground; Rowman \& Littlefield: Lanham, MD, USA, 2009.

19. Fekedulegn, D.; Hicks, R.R., Jr.; Colbert, J. Influence of topographic aspect, precipitation and drought on radial growth of four major tree species in an Appalachian watershed. For. Ecol. Manag. 2003, 177, 409-425. [CrossRef]

20. McNab, W.H. Terrain shape index: Quantifying effect of minor landforms on tree height. For. Sci. 1989, 35, 91-104.

21. Villwock, J.L.; Kabrick, J.M.; McNab, W.H.; Dey, D.C. Landform and terrain shape indices are related to oak site index in the Missouri Ozarks. In Proceedings of the 17th Central Hardwood Forest Conference, Lexington, KY, USA, 5-7 April 2010; General Technical Report NRS-P-78, U.S. Department of Agriculture, Forest Service, Northern Research Station: Newtown Square, PA, USA, 2011.

22. Lawson, E.R. Pinus echinata Mill. shortleaf pine. Silv. N. Am. 1990, 1, 316-326.

23. Schott, K.M.; Karst, J.; Landhäusser, S.M. The role of microsite conditions in restoring trembling aspen (Populus tremuloides Michx) from seed. Restor. Ecol. 2014, 22, 292-295. [CrossRef]

24. Kappes, H.; Clausius, A.; Topp, W. Historical Small-Scale Surface Structures as a Model for Post-Mining Land Reclamation. Restor. Ecol. 2012, 20, 322-330. [CrossRef]

25. Macdonald, S.E.; Landhäusser, S.M.; Skousen, J.; Franklin, J.; Frouz, J.; Hall, S.; Jacobs, D.F.; Quideau, S. Forest restoration following surface mining disturbance: Challenges and solutions. New For. 2015, 46, 703-732. [CrossRef]

(C) 2019 by the authors. Licensee MDPI, Basel, Switzerland. This article is an open access article distributed under the terms and conditions of the Creative Commons Attribution (CC BY) license (http://creativecommons.org/licenses/by/4.0/). 